\title{
"The role of the Sharia Supervisory Board and corporate governance mechanisms in enhancing Islamic performance - evidence from Indonesia"
}

\begin{tabular}{|c|c|}
\hline \multirow{5}{*}{ AUTHORS } & Ahmad Nurkhin (D https://orcid.org/0000-0003-4743-1134 \\
\hline & R https://publons.com/researcher/N-5002-2019 \\
\hline & Abdul Rohman (D https://orcid.org/0000-0001-7324-1874 \\
\hline & Ahmad Rofiq (D https://orcid.org/0000-0002-4631-1977 \\
\hline & Hasan Mukhibad (D https://orcid.org/0000-0001-8979-5169 \\
\hline ARTICLE INFO & $\begin{array}{l}\text { Ahmad Nurkhin, Abdul Rohman, Ahmad Rofiq and Hasan Mukhibad (2018). The } \\
\text { role of the Sharia Supervisory Board and corporate governance mechanisms in } \\
\text { enhancing Islamic performance - evidence from Indonesia. Banks and Bank } \\
\text { Systems, 13(4), 85-95. doi:10.21511/bbs.13(4).2018.08 }\end{array}$ \\
\hline DOI & http://dx.doi.org/10.21511/bbs.13(4).2018.08 \\
\hline RELEASED ON & Friday, 14 December 2018 \\
\hline RECEIVED ON & Friday, 06 April 2018 \\
\hline \multirow[t]{2}{*}{ ACCEPTED ON } & Thursday, 06 December 2018 \\
\hline & $(\mathrm{oc}) \mathrm{EY}$ \\
\hline LICENSE & $\begin{array}{l}\text { This work is licensed under a Creative Commons Attribution } 4.0 \text { International } \\
\text { License }\end{array}$ \\
\hline JOURNAL & "Banks and Bank Systems" \\
\hline ISSN PRINT & $1816-7403$ \\
\hline ISSN ONLINE & $1991-7074$ \\
\hline PUBLISHER & LLC "Consulting Publishing Company "Business Perspectives" \\
\hline FOUNDER & LLC "Consulting Publishing Company "Business Perspectives" \\
\hline
\end{tabular}

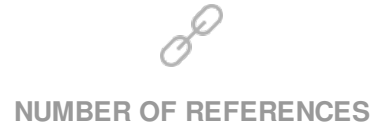

36

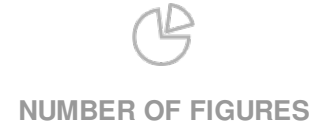

0
NUMBER OF TABLES

6

(C) The author(s) 2022. This publication is an open access article. 


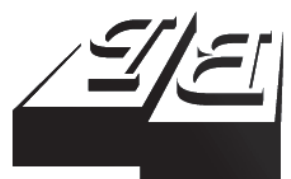

BUSINESS PERSPECTIVES

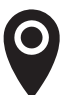

LLC "CPC "Business Perspectives" Hryhorii Skovoroda lane, 10, Sumy, 40022, Ukraine

www.businessperspectives.org

Received on: $6^{\text {th }}$ of April, 2018 Accepted on: $6^{\text {th }}$ of December, 2018

(C) Ahmad Nurkhin, Abdul Rohman, Ahmad Rofiq, Hasan Mukhibad, 2018

Ahmad Nurkhin, Master degree student, Economics Education Department, Economics Faculty, Universitas Negeri Semarang, Indonesia.

Abdul Rohman, Prof., Dr., Accounting Department, Economics and Business Faculty, Diponegoro University, Indonesia.

Ahmad Rofiq, Prof., Dr., Islamic Studies, Postgraduate, UIN Walisongo, Indonesia.

Hasan Mukhibad, Master degree student, Accounting Department, Faculty of Economics, Universitas Negeri Semarang, Indonesia.

\section{(c) (i)}

This is an Open Access article, distributed under the terms of the Creative Commons Attribution 4.0 International license, which permits unrestricted re-use, distribution, and reproduction in any medium, provided the original work is properly cited.
Ahmad Nurkhin (Indonesia), Abdul Rohman (Indonesia),

Ahmad Rofiq (Indonesia), Hasan Mukhibad (Indonesia)

\section{THE ROLE OF THE SHARIA SUPERVISORY BOARD AND CORPORATE GOVERNANCE MECHANISMS IN ENHANCING ISLAMIC PERFORMANCE - EVIDENCE FROM INDONESIA}

\begin{abstract}
This research aims to examine the correlation between the Sharia Supervisory Board (SSB) and corporate governance in terms of the performance of Islamic banks' Profitand-Loss Sharing (PLS) ratio, zakah performance and non-halal income ratio, and to analyze the relationship between risk and income for both PLS and murabahah financing and the PLS financing ratio. Non-halal income is a bank's income that is not in accordance with Sharia law. The object of this research was a sample of eleven commercial Islamic banks in Indonesia. The data are collected from each bank's annual report and corporate governance statement, for 2009-2016. This study uses the multiple regression analysis method. The results show that:

1. The size and educational background of the SSB has a significant and positive effect on the zakah performance (Islamic tax), and has a negative effect on the ratio of non-halal income. The size and educational background of the SSB has no impact on the PLS financing ratio.

2. Corporate governance has a significant and positive influence on the PLS financing ratio and zakah performance but has no influence on the non-halal income ratio.

3. The mudharaba risk and PLS revenue have a positive impact on the PLS financing ratio.

4. PLS financing risk and murabahah income have a negative impact on PLS financing ratio
\end{abstract}

Keywords

Sharia Supervisory Board, zakah, profit-and-loss sharing financing ratio, risk and revenue, corporate governance, Islamic performance

\section{JEL Classification G24, G32}

\section{INTRODUCTION}

Islamic banks are banks that use Sharia law as their operational system. Law of the Republic of Indonesia No. 21 of 2008 states that the Sharia principles used in Islamic banks are based on the fatwa of the National Sharia Board (DSN). The law also explains that, in order to ensure the fulfillment of Sharia principles, Islamic banks should establish a Sharia Supervisory Board (SSB).

In reality, the implementation of adherence to Sharia principles places more emphasis on the use of contracts or products owned by banks, such as mudharaba, musharaka, murabahah, etc. Sharia compliance reports, submitted by the SSB in the annual reports, emphasize the suitability of the products owned by the banks, in terms of their Sharia 
principles. Islamic banks' financing products can be divided into those that are equity based financing and fixed income based-financing. Equity based financing is a kind of financing where the bank would receive income based on a profit-and-loss sharing system. There are two contracts in the PLS system, which are mudharaba and musyarakah. On the other hand, fixed income based-financing would yield a fixed income for the bank. Murabahah, salam, istishna and ijarah are kinds of fixed income-financing. Basically, the general public demands compliance with Sharia principles, not only in terms of the products used by Islamic banks, but they also need compatibility with Sharia law in all the banks'operations, including in measuring bank performance.

The measurement of the performance of Islamic banks should be different, the performance measurement shoud be based on Sharia law. Kuppusamy et al. (2010) and Hameed et al. (2004) have developed a performance measurement formula, which is suitable for Islamic banks. The performance measurement are the PLS financing ratio (mudharaba and musharakah), income from PLS, and the halal revenue ratio. Mudarabah financing is a special kind of partnership, where a bank provide capital to its customers (mudarib) for investment in a commercial enterprise. In musyarakah financing, all the partners (a bank and a customer) could participate in the management and act as capital providers for the business, and can work for it.

This study was conducted to analyze the performance and compliance with Sharia principles of Islamic banks in Indonesia, with their SSBs' profiles as the predictor variable. The use of SSB variables is motivated by the task of the SSB, which is to oversee Islamic banks in fulfilling the principles of Sharia. Sharia compliance principles are measured by the PLS financing ratio, income from PLS, and non-halal revenue ratio.

The SSB profile variable is used to predict that the performance of Sharia compliance is limited, especially in Indonesia. This research is needed to fill this void and as a preliminary research to illustrate the effectiveness of the SSBs in performing their functions.

\section{LITERATURE REVIEW}

The main characteristic of Islamic banks is their compliance with Sharia principles. Islamic banks use Islamic law as the main source for their management and operations. The motive for developing Islamic banks is because of the practice of interest, gharar and maysir maysir (Mersni \& Othman, 2016) that are commonly used by conventional banks. Interest, gharar and maysir are transactions that are not suitable with Islamic law, so they must be replaced by other transactions which are allowed. The replacements for interest transactions are mudharaba, musyarakah, murabahah, salam, istishna and ijarah.

A further transformation occurs in an Islamic bank's accountability model. The different transactions of Islamic and conventional banks require different models for recording, recognizing and reporting their transactions in financial statements. Besides, their different business concepts lead to more complex financial statements from Islamic banks, which include commercial financial reports and social financial reports. In the context of Islamic banking in Indonesia, the commercial financial statements of the Islamic banks are their balance sheets, revenue statements, cash flow statements, equity change reports, and the notes to their financial statements. The social financial reports from the Islamic banks are the reports of their use of zakah funds and qardul hassan funds.

The other transformation is the performance model. Islamic banks and conventional banks have different principles, concepts, and philosophies, so the system used to measure their performance should be different (Syafii et al., 2012). Kuppusamy et al. (2010) and Hameed et al. (2004) have developed a method of measuring performance which is appropriate for the concept of Islamic banks, the ratio of PLS financing (mudharaba and musharaka), income of PLS financing and non-halal revenue ratio. 


\subsection{Sharia Supervisory Board and Islamic performance}

The main characteristic of Islamic banks is their compliance with Sharia law. Theoretically, the main characteristic of Islamic banks is the concept of profit-and-loss sharing as the alternative to the interest system that is used by conventional banks (Mallin, Farag, \& Ow-Yong, 2014). However, according to market demand, there are other systems (than profit and loss sharing), which are used by Islamic banks, including the system of trading and leasing.

The next development is the trading system. This is the most dominant system applied by Islamic banks (Abdul-Rahman \& Nor, 2016; Hameed et al., 2004), including in Indonesia (Anisykurlillah \& Mukhibad, 2016; Anisykurlillah \& Mukhibad, 2018). This fact proves that the performance of Islamic banks is not in accordance with their main characteristic. This is because the profitand-loss sharing system used in mudaraba and musharaka transactions is very fair compared to the other systems. Mudharaba and musyarakah transactions will give benefits to shohibul maal and mudharib if the investment funds generate profits. On the other hand, mudaraba and musharaka transactions will return a loss to shohibul maal and mudharib if the mudharaba investment funds produce a loss. This is the reason why mudharaba and musharaka transactions are more suitable with Sharia principles (because they are fairer) than other transactions (Abdul-Rahman \& Nor, 2016; Anisykurlillah et al., 2016; Anisykurlillah \& Mukhibad, 2018; Hasan, 1985; Sumarti, Fitriyani, \& Damayanti, 2014; Yasin, 2017).

The emerging Sharia financial system has a mission to fall in line with the current economic goals of broad economic prosperity, full and optimum levels of economic growth, justice in the socio-economy, a balanced distribution of revenue and wealth, and currency stability (Setiawan, 2006). From the various instruments available to Islamic banks, this mission is in proportion to mudharaba and musyarakah transactions (Abdul-Rahman \& Nor, 2016).

However, Islamic banks still have low levels of mudharaba and musyarakah financing. Islamic banks are more dominant in murabaha than mudharaba and musyarakah. This condition is not well-matched with the purpose of establishing Islamic banks. Abdul-Rahman and Nor (2016) consider that low mudharaba financing is due to its high levels of risk, caused by the high risk of investing; the difficulty in selecting appropriate partners, because the demand for it is mainly from low credit-worthy customers; and its lack of capital security.

The performance of profit-sharing financing is influenced by the implementation of Islamic Corporate Governance (ICG), which includes the Sharia Supervisory Board (SSB) (Asrori, 2014; Kuppusamy et al., 2010). Meanwhile, the SSB also has an impact on its bank's performance (Hassan et al., 2017; Marwan et al., 2016; Hassan et al., 2017; and Siswanti et al., 2017). The Sharia Supervisory Board has to guarantee all the bank's products are in accordance with Islamic law. Their products' compliance with Islamic law will increase their customers loyalty and will further improve the bank's performance.

\subsection{Good corporate governance and Islamic performance}

Corporate governance is the set of relationships between a company's management, its board, its shareholders and other stakeholders (Ghayad, 2008). The main focus of corporate governance is to ensure that a company's management fulfills all the interests of its stakeholders.

The implementation of GCG has been empirically proved to affect company performance (Aggarwal, 2013; Chapra \& Ahmed, 2002; Cheema \& Din, 2013; Esita \& Yanto, 2017; Ghaffar, 2014; Ghayad, 2008; Hassan et al., 2017; Heenetigala, 2011; Javed, 2006; Kalezi, 2012; Maher \& Andersson, 1999; Nawaz, 2017; Rehman et al., 2010; Sakawa \& Watanabel, 2011). Good company management will support the company in its revenue activities, and will have an impact on the improvement of the bank performance. In this research, the PLS financing ratio, income from the PLS financing ratio and non-halal revenue ratio are used. So, corporate governance has a positive impact on increasing Islamic performance. 


\subsection{The risks of Islamic financing and performance}

One of the indicators of Islamic performance is the PLS financing ratio. Abdul-Rahman and Nor (2016) considered that the low levels for mudhara$b a$ and musyarakah financing are due to the high risks in both types of financing. Mudharaba and musyarakah are contracts that have greater risks than the other types of financing (Aström, 2012; Ernawati, 2016). The high risks in this type of financing means Islamic banks don't provide it frequently. This has an impact on the low revenues and costs of the banks.

\section{METHODOLOGY}

The aims of this research are to prove empirically and to answer these hypotheses. They were developed as follows:

H1: The size of a bank's Sharia Supervisory Board has a significant influence on the bank's Islamic performance.

H2: The educational background of the Sharia Supervisory Board has a significant influence on the bank's Islamic performance.

H3: Good corporate governance has a significant influence on the bank's Islamic performance.

H4: $\quad$ PLS financing risk has a significant influence on the PLS financing ratio.

H5: Mudharaba financing risk has a significant influence on the PLS financing ratio.

H6: $\quad$ The income from PLS financing revenue has a significant influence on the PLS financing ratio.

H7: The murabahah margin's revenue has a significant influence on the PLS financing ratio.

Eight commercial Islamic banks in Indonesia are the object of this study. They are Bank Mualamat Indonesia, Bank BRI Sharia, BNI Sharia, Bank Sharia Mandiri, Bank Mega Sharia, Panin Islamic bank, BCA Sharia, and Bank Jabar Banten Sharia.
The observations of the study were carried out over an eight-year period (2009 to 2016).

The measurement of the research variables are as follows:

1. The Sharia Supervisory Board is measured by the size of the SSB, and the educational background of its members. The educational background of the SSB members is measured using a Likert scale, i.e. score 1 for a Doctor, score 2 for a Magister, and score 3 for other.

2. Corporate governance is measured by the Islamic disclosure index, with the formula

$$
\frac{\text { total score }}{\text { total all score }} \cdot 100 \% \text {. }
$$

3. Mudharaba risk is measured from the level of Non-Performing Loans (NPF) in mudharaba financing.

4. Income of the PLS financing ratio is measured from:

$\frac{\text { mudharabah and musyarakah income }}{\text { total income }} \cdot 100 \%$.

5. Revenue of murabahah financing ratio:

$$
\frac{\text { murabahah financing revenue }}{\text { total revenue }} \cdot 100 \% \text {. }
$$

6. PLS financing risk is measured from NonPerforming Financing (NPF) of mudharaba and musyarakah financing.

7. PLS financing ratio is measured from: $\frac{\text { mudharabahand musyarakah financing }}{\text { total financing }} \cdot 100 \%$.

8. Zakat performance is measured from:

$$
\frac{\text { zakahacceptance }}{\text { total assets }} \cdot 100 \% \text {. }
$$

9. Non-halal revenue ratio:

$$
\frac{\text { non-halal revenue }}{\text { total revenue }} \cdot 100 \% \text {. }
$$

The equation models that are developed in this study are: 


$$
\begin{aligned}
& \text { PLSRatio }=\text { SSB }+ \text { EDUSSB }+ \\
& + \text { GCGDI + MUDHARABARisk }+ \\
& + \text { REVPLS + REVMURABAHAH }+ \\
& + \text { PLSRisk + E, }
\end{aligned}
$$

- $\quad Z A K A H P E R F=S S B+$

$$
+E D U S S B+G C G I+E,
$$

$$
\begin{array}{ll} 
& \text { NONHALALREV }=S S B+ \\
& +E D U S S B+G C G I+E,
\end{array}
$$

where PLSRatio - Profit and Loss Sharing Financing Ratio; SSB - Sharia Supervisory Board; EDUSSB - Educational Background of SSB; GCGDI - Good Corporate Governance Disclosure Index; MUDHARABARisk - Mudharaba Financing Risk; REVPLS - PLS Revenue Ratio; REVMURABAHAH - Murabahah Revenue Ratio; PLSRisk - Profit and Loss Sharing Revenue Risk.

This study uses multiple regressions for the data analysis. The acceptance or rejection of the hypotheses is based on the significance value, which comes from the statistical aids. If the result of the Statistical Package For Social Scientists (SPSS) is greater than $5 \%$, then the hypothesis is rejected (Ghozali, 2013).

\section{RESULTS}

This study uses this following variable description (see Table 1).

Table 1 shows that Indonesian Islamic banks have at least two members on each Sharia Supervisory
Board, and at most three. The average educational background of the SSB members is 2.284. It means most of them hold a bachelor's degree and the rest either a master's or a doctorate. Islamic banks also have a good GCG disclosure index, shown by a score of $76.43 \%$. Islamic banks in Indonesia still have obstacles, almost all face a very large mudara$b a$ risk, which is $7.19 \%$ and the risk of profit sharing financing is $6.86 \%$. The impact of this high mudhar$a b a$ risk causes the banks' low revenue share, which is only $32.24 \%$. The PLS financing ratio is $34.22 \%$. The performance of Islamic banks in collecting zakah funds is $1.65 \%$ of their total assets, while the non-halal revenue earned by the banks is $1.55 \%$ of bank revenue.

\begin{tabular}{|c|c|c|c|c|c|}
\hline $\mathbf{R}$ & R Square & $\begin{array}{l}\text { Adjusted R } \\
\text { Square }\end{array}$ & $\begin{array}{l}\text { Std. error of } \\
\text { the estimate }\end{array}$ & $\mathbf{F}$ & Sig. \\
\hline $0.748 \mathrm{a}$ & 0.560 & 0.524 & 1.51409 & 21.493 & $0.000 \mathrm{~b}$ \\
\hline \multicolumn{6}{|c|}{ b. Dependent variable: PLS Financing Ratio } \\
\hline $0.748 \mathrm{a}$ & 0.560 & 0.524 & 1.51409 & 15.287 & $0.000 \mathrm{~b}$ \\
\hline \multicolumn{6}{|c|}{ b. Dependent variable: Zakah Performance } \\
\hline $0.778 \mathrm{a}$ & 0.606 & 0.572 & 1.52770 & 17.927 & $0.000 \mathrm{~b}$ \\
\hline
\end{tabular}

Testing for the acceptance or rejection of the hypotheses is done by testing the simultaneous and partial effects of the equation model that has been developed. The simultaneous relationships of the first, second and third models are as follows (see Table 2).

Table 2. Test result model

\begin{tabular}{|c|c|c|c|c|c|}
\hline Variable & No. & Minimum & Maximum & Mean & Std. deviation \\
\hline Size of Sharia Supervisory Board & 72 & 2.00 & 3.00 & 2.4444 & 0.50039 \\
\hline Educational Backgroud of Sharia Supervisory Board & 72 & 1.00 & 4.50 & 2.2847 & 0.74243 \\
\hline Corporate Governance Index & 72 & 0.00 & 1.00 & 0.7643 & 0.20359 \\
\hline Mudharaba Financing Risk & 72 & 0.00 & 1.00 & 0.0719 & 0.21664 \\
\hline PLS Revenue Ratio & 72 & 0.00 & 0.91 & 0.3224 & 0.20932 \\
\hline Murabahah Financing Revenue Ratio & 72 & 0.00 & 1.00 & 0.6394 & 0.22349 \\
\hline PLS Risk & 72 & 0.00 & 0.80 & 0.0686 & 0.14238 \\
\hline PLS Financing Ratio & 72 & 0.00 & 0.91 & 0.3422 & 0.21791 \\
\hline Zakah Performance & 72 & 0.00000 & 0.36390 & 0.0164549 & 0.06867152 \\
\hline Non-Halal Revenue Ratio & 72 & 0.00000 & 0.30080 & 0.0154930 & 0.06384086 \\
\hline
\end{tabular}

Table 2 explains that the three models developed in this study were accepted, becuse all the models have a significance value of 0.000 . The value is $0.000<$ 0.05 , so empirically the model is accepted.

Table 1. Variable description

Sources: Output of SPSS. 
Table 3. Partial test result from Model 1

\begin{tabular}{|c|c|c|c|c|}
\hline $\begin{array}{c}\text { Independent } \\
\text { variable }\end{array}$ & Dependent variable & $\begin{array}{l}\text { Unstandardized } \\
\text { coefficients }\end{array}$ & Sig. & Conclusion \\
\hline \multirow{8}{*}{$\begin{array}{l}\text { PLS Financing } \\
\text { Ratio }\end{array}$} & Constants & 0.142 & 0.365 & \\
\hline & $\begin{array}{l}\text { Number of Members of Sharia Supervisory } \\
\text { Board }\end{array}$ & -0.054 & 0.103 & $\mathrm{Ha}$ is rejected \\
\hline & $\begin{array}{l}\text { Educational Background of Sharia Supervisory } \\
\text { Board }\end{array}$ & -0.006 & 0.769 & $\mathrm{Ha}$ is rejected \\
\hline & Corporate Governance Index & 0.156 & 0.050 & Ha is accepted \\
\hline & Mudharaba Risk & -0.012 & 0.886 & $\mathrm{Ha}$ is rejected \\
\hline & Revenue Profit Sharing Ratio & 0.762 & 0.000 & Ha is accepted \\
\hline & Murabaha Financing Margin Ratio & -0.005 & 0.967 & $\mathrm{Ha}$ is rejected \\
\hline & Risk of PLS Financing & -0.212 & 0.068 & Ha is accepted \\
\hline
\end{tabular}

Note: Significance level at $10 \%$.

Partial hypotheses test results are as in Tables 3-5.

Table 3 shows that there are four rejected hypotheses, two accepted hypotheses (with a significance level of 5\%) and one accepted hypothesis with a significance level of $10 \%$. The accepted hypotheses prove that there is a significant and positive relationship between corporate governance and the PLS financing ratio. In addition, it is empirically proven that there is a significant and positive influence between the PLS revenue and the ratio of PLS financing. The PLS financing ratio is significantly and positively influenced by the PLS risk.

Table 4 shows that all the hypotheses are accepted. These findings indicate that there is a significant and positive relationship between the number of people on a Sharia Supervisory Board with the performance of $z a k a h$. The educational background of the Sharia Supervisory Board also has a positive influence on the performance of zakah. It also proved a significant and positive link between the performance of zakat and corporate governance index.

Table 5 shows that there is a significant and positive relationship between the number of persons on a Sharia Supervisory Board and non-halal revenue ratios. Empirical evidence also proves that there is a positive relationship between the Sharia Supervisory Board's background and non-halal revenue. In addition, there is a significant and positive relationship between corporate governance and non-halal revenue ratios.

Tables 3, 4 and 5 can be summarized in Table 6 .

Table 4. Partial test result from Model 2

\begin{tabular}{|c|c|c|c|c|}
\hline $\begin{array}{l}\text { Independent } \\
\text { variable }\end{array}$ & Dependent variable & $\begin{array}{l}\text { Unstandardized } \\
\text { coefficients }\end{array}$ & Sig. & Conclusion \\
\hline \multirow{4}{*}{ Zakah Performance } & Constants & -6.804 & 0.000 & \\
\hline & $\begin{array}{l}\text { Number of Members of Sharia Supervisory } \\
\text { Board }\end{array}$ & 3.053 & 0.016 & Ha is accepted \\
\hline & $\begin{array}{l}\text { Educational Background of Sharia Supervisory } \\
\text { Board }\end{array}$ & -3.944 & 0.000 & $\mathrm{Ha}$ is accepted \\
\hline & Corporate Governance Index & 2.083 & 0.016 & Ha is accepted \\
\hline
\end{tabular}

Table 5. Partial test result from Model 3

\begin{tabular}{|c|c|c|c|c|}
\hline $\begin{array}{l}\text { Independent } \\
\text { variable }\end{array}$ & Dependent variable & $\begin{array}{l}\text { Unstandardized } \\
\text { coefficients }\end{array}$ & Sig. & Conclusion \\
\hline \multirow{4}{*}{$\begin{array}{l}\text { Non-Halal Revenue } \\
\text { Ratio }\end{array}$} & Constants & 6.814 & 0.000 & \\
\hline & $\begin{array}{l}\text { Number of Members of Sharia Supervisory } \\
\text { Board }\end{array}$ & 3.268 & 0.011 & Ha is accepted \\
\hline & $\begin{array}{l}\text { Educational Background of Sharia Supervisory } \\
\text { Board }\end{array}$ & -5.195 & 0.000 & Ha is accepted \\
\hline & Corporate Governance Index & 0.785 & 0.341 & Ha is rejected \\
\hline
\end{tabular}


Table 6. Acceptance or rejection of hypotheses

\begin{tabular}{|c|c|c|}
\hline \multirow{3}{*}{ Ha1 } & $\begin{array}{l}\text { The size of the Sharia Supervisory Board has a significant influence on Islamic performance (PLS } \\
\text { financing ratio) }\end{array}$ & Ha is rejected \\
\hline & $\begin{array}{l}\text { The size of the Sharia Supervisory Board has a significant influence on Islamic performance (zakah } \\
\text { performance) }\end{array}$ & Ha is accepted \\
\hline & $\begin{array}{l}\text { The size of the Sharia Supervisory Board has a significant influence on Islamic performance (non-halal } \\
\text { revenue ratio) }\end{array}$ & Ha is accepted \\
\hline \multirow{3}{*}{$\mathrm{Ha} 2$} & $\begin{array}{l}\text { The educational background of the Sharia Supervisory Board has a significant influence on Islamic } \\
\text { performance (PLS financing ratio) }\end{array}$ & Ha is rejected \\
\hline & $\begin{array}{l}\text { The educational background of the Sharia Supervisory Board has a significant influence on Islamic } \\
\text { performance (zakah performance) }\end{array}$ & Ha is accepted \\
\hline & $\begin{array}{l}\text { The educational background of the Sharia Supervisory Board has a significant influence on Islamic } \\
\text { performance (non-halal revenue ratio) }\end{array}$ & Ha is accepted \\
\hline \multirow{3}{*}{ Ha3 } & Good corporate governance has a significant influence on Islamic performance (PLS financing ratio) & Ha is accepted \\
\hline & Good corporate governance has a significant influence on Islamic performance (zakah performance) & Ha is accepted \\
\hline & $\begin{array}{l}\text { Good corporate governance has a significant influence on Islamic performance (non-halal revenue } \\
\text { ratio) }\end{array}$ & Ha is rejected \\
\hline $\mathrm{Ha} 4$ & PLS risk affects the PLS financing ratio & Ha is rejected \\
\hline Ha5 & The mudharaba financing risk affects the PLS financing ratio & Ha is accepted \\
\hline Ha6 & The income of PLS finance revenue affects the PLS financing ratio & Ha is accepted \\
\hline $\mathrm{Ha}$ & The ratio of murabahah revenue affects the PLS financing ratio & Ha is rejected \\
\hline
\end{tabular}

\section{DISCUSSION}

The results of this research show that the size of a Sharia Supervisory Board did not affect the financing performance of Islamic banking. The profit-sharing financing ratio is not affected by the size of a Sharia Supervisory Board. The results of this study were different from the results of Kuppusamy et al. (2010), which showed that there was a positive relationship between the Sharia Supervisory Board and the ratio of financing. The results of this study also reject the findings of Asrori (2014) who found that Islamic corporate governance (including the role of the SSB) does affect the ratio of profit-sharing financing. The measurement of the Sharia Supervisory Board using their educational background found the same thing, there is no significant relationship between the educational background of the SSB and the profit-sharing financing ratio.

The results of this study prove that the Sharia Supervisory Boards are more focused on their task; ensuring their bank's compliance with Sharia principles, in the form of offering Sharia products. Every product provided by an Islamic bank must be assessed in accordance with Sharia principles by the SSB. The SSB has the responsibility to follow up on the tasks and the validity of the transactions implemented by Islamic banks (Marwan et al., 2016). It means that the SSB ensures that Islamic banks used mudharaba financing contracts, musharaka, murabaha and other contracts that are suitable with Sharia. In other words, all financing (based on profit sharing or trading) has been in accordance with Sharia law, so that all the contracts can be applied by Islamic banking.

The number and the educational background of the Sharia Supervisory Board has an individual, positive and significant relationship to the performance of zakah. The greater the number of members a supervisory council has, the more improved zakat performance will be, as measured by the amount of zakah accepted. In addition, the higher the educational background the commissioners have, the more zakat will be collected by an Islamic bank. Mukhibad et al. (2017) used the Islamic corporate disclosure variable (including SSB disclosure) to predict zakah performance. The results of the research found there is a significant relationship between Islamic corporate disclosure and the zakat collected by banks. It also confirmed the results of Rahman and Bukair (2013) who found a significant relationship between an SSB and its CSR disclosure (including zakah disclosure). Zakah is a Muslim obligation (Rahman \& Bukair, 2013; Hassan et al., 2009) which is collected and distributed based on Sharia law. This reason shows the relationship between SSB and zakah's aggregation. The fund distribution rules are described in Quran Attaubah verse 60.

"Zakah expenditures are only for the poor and for the needy and for those employed to col- 
lect [zakah] and for bringing hearts together [for Islam] and for freeing captives [or slaves] and for those in debt and for the cause of Allah and for the [stranded] traveler - an obligation [imposed] by Allah. And Allah is Knowing and Wise".

The number and educational background of a Sharia Supervisory Board's members have an individual, negative and significant relationship with non-halal revenue ratios. The number of SSB members will have an effect on the amount of non-halal revenue received by the bank. The educational background of the SSB members will decrease non-halal revenue. The SSB has a controlling function, supervising its bank's transactions, including controlling the revenue that comes from illicit activities or what is commonly called non-halal revenue. The SSB has a supervising and controlling function over the management's performance (Mersni \& Othman, 2016), so that the greater the number of SSB members, and the higher their education levels are, the more effectively the SSB will carry out its control functions, including controlling the non-halal revenue. For an Islamic bank, non-halal revenue should not be recognized as revenue in the comprehensive revenue statement, but it is recognized as an entry in the benevolent fund (Indonesian Institute of Accountants, 2017).

This study also uses corporate governance as an independent variable for predicting Islamic banks' performance, which is measured by the PLS financing ratio, zakah performance and non-halal revenue ratio. The results match the previous research results that there is a positive relationship between CG and the ratio of PLS financing and zakat performance. That is, good CG implementation will have an impact on increasing the profit-sharing ratio. Good CG will have an impact on improving the commitment of a bank's management to improve the PLS financing ratio. This is because PLS financing has a higher return than financing based on trading (Abdul-Rahman \& Nor, 2016; Ernawati, 2016). However, PLS financing also has a higher risk than financing based on trading (AbdulRahman \& Nor, 2016; Ernawati, 2016). Even so, PLS financing is more profitable than other types of financing (Hasan, 1985).

In addition, good CG implementation can impact the amount of zakat that is collected by banks.
These results agree with the research by Mukhibad et al. (2017) who found GCG has a significant effect on zakah's performance. These findings prove that zakah, as a source of social funding revenue, needs the attention of Islamic bankings' management to improve its performance. Zakat funds can be used by Islamic banks as a source of funds for their CSR activities, and furthermore this CSR can be used as an independent variable that will impact by increasing bank profitability. This is proved by Platonova, Asutay, Dixon, and Mohammad (2016), and Tsoutsoura (2004) who all found a significant relationship between CSR and bank profitability.

Another source of social funds for Islamic banks is non-halal funds. The results of this study prove that there is no significant relationship between CG and non-halal revenue. That is, non-halal revenue is not a concern for a bank's management, because this revenue is forbidden revenue and should be avoided. Because Islamic banks are banks that use Sharia principles, it is not proper that they increase their non-halal revenue or use it as a funding source for their social activities.

Another finding of this study is a significant and positive relationship between the profit-sharing financing ratio and the level of mudaraba risk, and this is not influenced by the risk from general PLS financing. The types of PLS financing are mudaraba and musharakah. Mudharaba financing has a greater risk than musyarakah financing. Mudharaba financing has the greater potential for agency conflicts than musharaka financing (Ernawati, 2016), because with musyarakah financing the customer also provides part of the funding for the business. With mudharaba financing, the entire business capital comes from the bank, so this type of transaction needs honest customers who can manage and honestly report the results of their business operations. Abdul-Rahman and Nor (2016) consider that the low level of mudharaba financing by Islamic banks is due to its higher investment risk, the difficulty in finding the right customers, and low levels of customer honesty.

The results also show that the ratio of mudhara$b a$ financing is influenced by the revenue sharing received by the bank, but not influenced by the amount of murabahah returns. It means that 
Islamic banks will provide mudharaba financing if it has a high revenue. If the profit-sharing financing ratio is associated with the murabahah returns and produces no relationship between profit-sharing financing ratio and murabahah returns, it can be interpreted that they are not substituted, but both are complementary. Islamic banks will not reduce their mudharaba financing if the returns obtained from it are high, otherwise Islamic bank financing will not increase. Mudharaba financing is preferred if the revenue derived from murabahah financing is low.

\section{CONCLUSION}

The findings of this study show that the size and educational background of a Sharia Supervisory Board has a significant positive relationship with zakah performance, and a negative relationship with the non-halal revenue ratio. The number of members of a Sharia Supervisory Board and their educational background have no relationship with the non-halal financing ratio. On the other hand, corporate governance has a significant and positive influence on the profit-sharing financing ratio and zakah performance; yet it has no relationship with the ratio of non-halal revenue. These results indicate that the SSBs play a more important role than just to increase the profit-sharing financing ratio, in their supervision of the compliance of the transactions conducted by Islamic banks with Sharia principles. They also ensure the PLS financing and Islamic trade financing have been in accordance with Sharia principles.

The PLS financing ratio is also positively influenced by mudharaba financing risks and the level of profit-sharing returns. The profit-sharing ratio is not affected by the level of profit sharing financing risk (mudharaba and musyaraka) and murabahah margin's revenue. It is considered that mudharaba and musyaraka financing do not have substitution characteristics but they do have complementary characteristics. Islamic banks will provide profit-sharing financing if they receive suitable returns and a low level of risk, as well as having no relation with the returns or Islamic trade financing risk.

Islamic banks in Indonesia are the object of this study. Regarding the risk, profit sharing ratio, and the regulations that arrange the role of each bank's SSB and corporate governance, this study would show different findings if the object of the study was Islamic banking in some other country, rather than in Indonesia. For future studies, it is suggested that researchers do use other countries as their object of research. The findings and results of this study can be used as references for the policy makers to optimize the role of Islamic bankings' management in general and to improve the PLS financing ratio.

\section{REFERENCES}

1. Abdul-Rahman, A., \& Nor, S. M. (2016). Challenges of Profitand-Loss Sharing Financing in Malaysian Islamic Banking. Malaysian Journal of Society and Space, 12(2), 39-46. Retrieved from http://ejournal.ukm.my/ gmjss/article/view/17726

2. Aggarwal, P. (2013). Impact of Corporate Governance on Corporate Financial Performance. Journal of Business and Management, 13(3), 1-5. https:// doi.org/10.9790/487X-1330105

3. Anisykurlillah, I., \& Mukhibad, H. (2018). Empirical Proof of Traditional Market Trader
Readiness in Preparing Financial Statement as a Mudharaba Transaction Media. Australasian Journal of Islamic Finance and Business, 4(1), 11-18. Retrieved from http://www.ajifb.net.au/ index.php/AJIFB/article/view/29

4. Anisykurlillah, I., Fachrurrozie, \& Mukhibad, H. (2016). A Financial Report Model For Traditional Market Traders To Increase Mudharaba Financing In Baitul Maal Wattamwil (BMT). Review of Integrative Business and Economics Research Online, 5(1), 219-228. Retrieved from http://sibresearch. org/uploads/2/7/9/9/2799227/ riber_h15-126_219-228.pdf
5. Asrori. (2014). Implementasi Islamic Corporate Governance dan Implikasinya Terhadap Kinerja Bank Syariah. Jurnal Dinamika Akuntansi, 6(1), 90-102. Retrieved from https://journal. unnes.ac.id/nju/index.php/jda/ article/view/3249

6. Aström, Z. H. (2012). Risk Analysis for Profit and Loss Sharing Instruments. Sarajevo: International University of Sarajevo.

7. Chapra, U., \& Ahmed, H. (2002). Corporate Governance In Islamic Financial Institutions. Islamic Development Bank- 
Islamic Research and Training Institute. Islamic Development Bank. Retrieved from https:// www.researchgate.net/publication/303501210_Corporate_Governance_in_Islamic_Financial_Institution

8. Cheema, K. U. R., \& Din, M. S. (2013). Impact of Corporate Governance on Performance of Firm: A Case Study of Cement Industry in Pakistan. Journal of Business and Management Sciences, 4(1), 44-46. Retrieved from https://mpra.ub.unimuenchen.de/53202/

9. Ernawati, E. (2016). Risk of Profit Loss Sharing Financing: the Case of Indonesia. Al-Iqtishad: Journal of Islamic Economics, 8(1), 101116. https://doi.org/10.15408/aiq. v8i1.2511

10. Esita, P., \& Yanto, H. (2017). The Effect of Good Corporate Governance Mechanism (Managerial Ownership) on Corporate Value with Environmental Performace as An Intervening Variable. Accounting Analysis Journal, 5(3), 220-228.

11. Ghaffar, A. (2014). Relationship of Islamic Bank's Profitability with Corporate Governance Practices. European Journal of Business an Management, 6(17), 141-150.

12. Ghayad, R. (2008). Corporate Governance and The Global Performance of Islamic Banks. Humanomics, 24(3), 207-216. https://doi. org/10.1108/08288660810899368

13. Ghozali, I. (2013). Aplikasi Analisis Multivariate Dengan Program IBM SPSS 21. Semarang: FE Universitas Diponegoro.

14. Hameed, S., Wirman, A., Alrazi, B., Nazli, M., \& Pramono, S. (2004). Alternative Disclosure \& Performance Measures For Islamic Banks. In Second Conference on Administrative Sciences: Meeting the Challenges of the Globalization Age (pp. 1-37). Dhahran, Saudi Arabia: King Fahd University of Petroleum \& Minerals, Dhahran, Saudi Arabia.

15. Hasan, Z. (1985). Determination of Profit and Loss Sharing Ratios in Interest-Free Business Finance. Journal of Research in Islamic Economics, 3(1), 13-29. Retrieved from https://mpra.ub.unimuenchen.de/3013/

16. Hassan, A., \& Latiff, H. S. B. A. L. (2009). Corporate Social Responsibility of Islamic Financial Institutions and Businesses: Optimizing charity value. Humanomics, 25(3), 177-188. https://doi. org/10.1108/08288660910986900

17. Hassan, M., Rizwan, M., \& Sohail, H. M. (2017). Corporate Governance, Shariah Advisory Boards and Islamic Banks' Performance Corporate. Pakistan Journal of Islamic Research, 18(1), 173-184. Retrieved from http:// www.bzu.edu.pk/pjir.php

18. Heenetigala, K. (2011). Corporate Governance Practices and Firm Performance of Listed Companies in Sri Lanka. Victoria University.

19. Javed, A. Y. I. R. (2006). Corporate Governance and Firm Performance: Evidence from Karachi Stock Exchange. The Pakistan Development Review, 45(4), 947-964. Retrieved from https://www.jstor.org/stable/41260661

20. Kalezić, Z. (2012). Corporate Governance and Firm Performance With Special Reference To The Banking System: Empirical Evidence From Monetengro. Journal of Central Banking Theory and Practice, 2(August), 19-54. Retrieved from https://www.cbcg.me/slike_i_fajlovi/fajlovi/journal/vol1/no2/ corporate_governance.pdf

21. Kuppusamy, M., Saleh, A. S., \& Samudhram, A. (2010). Measurement of Islamic Banks Performance Using a Shariah Conformity and Profitability Model. Review of Islamic Economic, 13(2), 35-48.

22. Maher, M., \& Andersson, T. (1999). Corporate Governance: Effect on Firm Performance and Economic Growth. Organisation For Economic Co-Operation And Development.

23. Mallin, C., Farag, H., \& OwYong, K. (2014). Corporate social responsibility and financial performance in Islamic banks. Journal of Economics Behavior \& Organization, 103, s21-s38. http://dx.doi.org/10.1016/j. jebo.2014.03.001

24. Marwan, M., Injas, Y., Haron, M. S., Ramli, R., \& Injas, R. A. (2016). The Importance Of The Shari'ah Supervisory Boards (SSBS) In The Islamic Banking System. South East Asia Journal of Contemporary Business, Economics and Law, 9(2), 25-31. Retrieved from http:// seajbel.com/wp-content/uploads/2016/05/K9_65.pdf

25. Mersni, H., \& Othman, H. Ben. (2016). The impact of corporate governance mechanisms on earnings management in Islamic banks in the Middle East region. Journal of Islamic Accounting and Business Research, 7(4), 318-348. https://doi.org/10.1108/ JIABR-11-2014-0039

26. Mukhibad, H., Kiswanto, \& Jayanto, P. Y. (2017). An Analysis on Financial and Social Performance of Islamic Banks in Indonesia. International Journal of Monetary, Economic Finance, 10(3/4), 295-308.

27. Nawaz, T. (2017). Exploring the Nexus Between Human Capital, Corporate Governance and Performance: Evidence from Islamic Banks. Journal of Business Ethics, 10551(s), 1-47. https://doi. org/10.1007/s10551-017-3694-0

28. Platonova, E., Asutay, M., Dixon, R., \& Mohammad, S. (2016). The Impact of Corporate Social Responsibility Disclosure on Financial Performance: Evidence From GCG Islamic Banking Sector. Journal of Business Ethics, 151(2), 451-471. https://doi. org/10.1007/s10551-016-3229-0

29. Rahman, A. A., \& Bukair, A. A. (2013). The Influence of the Shariah Supervision Board on Corporate Social Responsibility Disclosure by Islamic Banks of Gulf Co-Operation Council Countries. Asian Journal of Business and Accounting, 6(2), 65-104. Retrieved from https:// ajba.um.edu.my/index.php/AJBA/ article/view/2678 
30. Rehman, R. U., \& Mangla, I. U. (2010). Corporate Governance and Performance of Financial Institutions in Pakistan:

A Comparison between Conventional and Islamic Bank in Pakistan. The Pakistan Development Review, 49(4), 461475. https://doi.org/10.30541/ v49i4iipp.461-475

31. Sakawa, H., \& Watanabel, N. (2011). Corporate Board Structures and Performance in the Banking Industry: Evidence from Japan. SSRN Electronic Journal. https://doi.org/10.2139/ ssrn. 1786200

32. Siswanti, I., Salim, U., Sukoharsono, E. G., \& Aisjah, S. (2017). Sustainable Business of Islamic Bank Through on the Islamic Corporate Governance and Islamic Financial Performance. Journal of Finance and Banking Review, 2(2), 15-20. Retrieved from http://gatrenterprise.com/ GATRJournals/sustainable_business_of_islamic_bank_through on_the_islamic_corporate_governance_and_islamic_financial_performance.html

33. Sumarti, N., Fitriyani, V., \& Damayanti, M. (2014). A Mathematical Model of the Profit-Loss Sharing (PLS) Scheme. Procedia - Social and Behavioral Sciences, 115, 131-137. https://doi. org/10.1016/j.sbspro.2014.02.421

34. Syafii, M., Sanrego, Y. D., \& Taufiq, M. (2012). An Analysis of Islamic Banking Performance: Maqashid Index Implementation in Indonesia and Jordania. Journal of Islamic Finance, 1(1), 12-29. Retrieved from http://journals. iium.edu.my/iiibf-journal/index. $\mathrm{php/jif/article/view/2}$

35. Tsoutsoura, M. (2004). Corporate Social Responsibility and Financial Performance. California: University of California at Berkeley. Retrieved from https://escholarship.org/uc/ item/111799p2

36. Yasin, H. M. (2017). Islamic Banking - Banking On Virtue. IDLC Monthly Business Review, 1(1), 2-12. Retrieved from http:// idlc.com/public/documents/ mbr/17/Monthly\%20Business\%20Review\%20-\%20January\%202017.pdf 